\title{
Development and reprotuction of Spodoptera eridania on natural hosts and artificial diet
}

\author{
A. Silva ${ }^{a}$, C. A. Baronio * , E. C. W. Galzer ${ }^{b}$, M. S. Garcia ${ }^{a}$ and M. Botton ${ }^{b}$ \\ aPrograma de Pós-graduação em Fitossanidade, Departamento de Fitossanidade, Universidade Federal de Pelotas - UFPel, \\ Campus Universitário, s/n, Caixa Postal 354, CEP 96010-900, Pelotas, RS, Brasil \\ 'baboratório de Entomologia, Embrapa Uva e Vinho, Rua Livramento, 515, Caixa Postal 130, CEP 95700-000, \\ Bento Gonçalves, RS, Brasil \\ *e-mail: cleber.baronio@hotmail.com
}

Received: March 18, 2017 - Accepted: August 3, 2017 - Distributed: February 28, 2019

\begin{abstract}
The development and reproductive potential of Spodoptera eridania (Stoll, 1782) (Lepidoptera, Noctuidae) was compared on natural and artificial diets. Its biology was determined under laboratory conditions, providing an artificial diet, leaves of white clover and the peach cultivar 'Chimarrita' and fruits and leaves of the apple cultivar 'Gala'. Larvae of $S$. eridania could not complete their biological cycle when fed on apple fruits or peach leaves. The artificial diet provided the shortest development time, with a cycle of $28.5 \pm 0.14$ days from egg to adult and $37.3 \%$ total viability. Apple leaves led to a longer development time from egg to adult (62.8 \pm 1.22 days) and lower total viability (23\%) and white clover provided the highest total viability (54.3\%). The results showed that S. eridania can use white clover and apple leaves to develop normally in apple orchards. The reduction of food sources such as white clover used by the larvae results in infestation and damage to fruits from "test bites".
\end{abstract}

Keywords: southern armyworm, life-cycle, reproduction, Prunus persica, Malus domestica, Trifolium repens.

\section{Desenvolvimento e reprodução de Spodoptera eridania em hospedeiros naturais e dieta artificial}

\begin{abstract}
Resumo
O desenvolvimento e o potencial reprodutivo de Spodoptera eridania (Stoll, 1782) (Lepidoptera, Noctuidae) foi comparado em dietas naturais e artificial. A biologia de S. eridania foi determinada em condições de laboratório, comparando-se uma dieta artificial com folhas de trevo branco e de pêssego da cultivar 'Chimarrita' e frutos e folhas de maçã da cultivar 'Gala'. As larvas de S. eridania não puderam completar seu ciclo biológico quando alimentadas com frutas de maçã ou folhas de pêssego. A dieta artificial proporcionou o menor tempo de desenvolvimento, com um ciclo completo de $28,5 \pm 0,14$ dias de ovo a adulto e $37,3 \%$ de viabilidade total. As folhas de maçã levaram maior tempo de desenvolvimento de ovo a adulto $(62,8 \pm 1,22$ dias) e menor viabilidade total $(23 \%)$. O trevo branco apresentou a maior viabilidade total $(54,3 \%)$. Os resultados mostraram que $S$. eridania pode usar trevo branco e folhas de maçã para se desenvolver normalmente em pomares de maçã. A redução de fontes alimentares, como o trevo branco usado pelas larvas, resulta em infestação e danos aos frutos através das "mordidas de prova".
\end{abstract}

Palavras-chave: lagarta da vagem, ciclo evolutivo, reprodução, Prunus persica, Malus domestica, Trifolium repens.

\section{Introduction}

The southern armyworm Spodoptera eridania (Stoll, 1782) (Lepidoptera: Noctuidae) is a native species that is widespread in tropical regions of the Americas (Pogue, 2002). It has been recorded from 202 host species belonging to 58 families (Montezano et al., 2014). In the last few years, S. eridania has been recognized as a pest of annual crops, such as cotton Gossypium hirsutum L. and soybean Glycine max (L.) (Favetti et al., 2015; Santos et al., 2005, 2010), tomato Lycopersicon esculentum Mill. (Miranda et al., 2005), and strawberry Fragaria $x$ ananassa Duch.

(Bortoli et al., 2012); and of perennial crops, such as fruit trees of temperate climates, e.g., apple (Nora and Reis Filho, 1988) and peach Prunus persica L. (Botton et al., 2012), and grapevines Vitis vinifera L. (Bortoli et al., 2012). This polyphagy causes important losses and contributed to the rapid adaptation of this pest to different agroecosystems (Bortolotto et al., 2014).

In apple and peach orchards, the occurrence of lepidopteran insects is limited to a group of species that use annual crops such as soybean and maize Zea mays 
L. as a primary source of food. These insects migrate to orchards when they cannot obtain food from their normal primary hosts (Fonseca, 2006; Santos et al., 2010; Nunes et al., 2013). In orchards, S. eridania is most frequent on cultivation systems that maintain cover vegetation with spontaneous plants, including clover Trifolium spp., chaptalia Chaptalia nutans, and dandelion Taraxacum spp. (Capinera, 1999). However, in many cases, fruit are damaged only when the preferred spontaneous plants are not available due to larval consumption or by the use of herbicides (Nora and Reis Filho, 1988; Capinera, 1999; Botton et al., 2012; Efrom et al., 2014).

One fundamental step in implementing a pest-management program is the knowledge wild plants such as whit clover Trifolium repens L. that occur spontaneously in orchards. Moreover, there is no information on artificial diets for rearing this species in the laboratory for management and control purposes. The present study determined biological parameters of S. eridania fed on leaves and fruits of apple and on leaves of white clover and peach, comparing its performance to insects fed on artificial diet, under laboratory conditions.

\section{Material and Methods}

The biology of $S$. eridania was determined in the Entomology Laboratory at Embrapa Uva e Vinho, Bento Gonçalves, Rio Grande do Sul, in climate chambers regulated at a temperature of $25 \pm 1^{\circ} \mathrm{C}$, relative humidity of $60 \pm 10 \%$ and photophase of 14 hours. Eggs and larvae of $S$. eridania were collected in a vineyard located in the municipality of Bento Gonçalves, transported to the laboratory, placed in plastic containers and reared on the artificial diet of Burton and Perkins (1972). The study of the biology began after three generations in which insects were kept under laboratory conditions.

This study was conducted to compare the development of S. eridania on an artificial diet described by Greene et al. (1976), with development on natural hosts present in orchards: leaves and fruits of apple Malus domestica 'Gala', leaves of peach Prunus persica 'Chimarrita', or leaves of white clover Trifolium repens. Also, neonate larvae were fed up to the third instar with the artificial diet, and subsequently fed on M. domestica 'Gala' fruits. The leaves used in the experiments were harvested in the early hours of the day in orchards where no insecticides had been used, transported to the laboratory, and immersed for $1 \mathrm{~min}$ in a solution containing 1\% sodium hypochlorite for disinfection and washed under water.

The traits evaluated were: embryonic period and egg viability; duration and viability of larval and pupal stages; number of instars in the larval stage; pupal weight of males and females at 24 hours of age; sex ratio; adult longevity; pre-oviposition period; and female fecundity. A fertility life table was constructed from the data obtained.

\subsection{Embryonic period}

To determine the duration and viability of the embryonic period, when there were, all the eggs laid at the second oviposition of each female were counted, separated, and kept on moistened filter paper in Petri dishes of $6.5 \mathrm{~cm}$ diameter, and the number of larvae hatched were counted daily.

\subsection{Larval stage}

To determine the biological parameters of the immature stage, 150 newly hatched larvae were placed in individual flat-bottom glass tubes $(8.5 \mathrm{~cm}$ long x $2.5 \mathrm{~cm}$ diameter) containing artificial diet or leaves of the natural hosts evaluated. Other larvae were fed the artificial diet in a glass tube until the third instar, when they were transferred to transparent plastic containers of $250 \mathrm{ml}$ capacity containing an apple fruit. Duration and viability of the larval and pre-pupal stages were calculated based on observation of these 150 individuals.

\subsection{Pupal stage}

Individuals at the pupal stage were transferred to flat-bottom glass tubes $(8.5 \mathrm{~cm} \times 2.5 \mathrm{~cm})$ containing moistened filter paper and buffered with hydrophilic cotton, where they remained in a heated chamber (Temperature: $25 \pm 1{ }^{\circ} \mathrm{C}$, RH $60 \pm 10 \%$ and photophase: 14 hours) until the adults emerged. The pupae were sexed according to Butt and Cantu (1962) and weighed after $24 \mathrm{~h}$.

\subsection{Adult stage}

To obtain data on the pre-oviposition period, longevity, and fecundity of females, 20 couples of the same age were formed whenever possible, placed in individual PVC cages (10 cm diameter x $10 \mathrm{~cm}$ high) covered with office paper on the sides, voile fabric on the top, and filter paper at the bottom. The couples were fed daily with a $15 \%$ honey solution, provided on cotton tufts in plastic containers ( $2 \mathrm{~cm}$ diameter $\times 1 \mathrm{~cm}$ high).

\subsection{Statistical analysis}

Results for the different stages were subjected to exploratory analyses to assess the assumptions of normality of residuals (Shapiro and Wilk, 1965), and non-normal data were transformed by ARSEN (SQUARE ROOT (X)). The means for each stage were subjected to analysis of variance and compared by Tukey's test at $5 \%$ probability, using the program SPSS 24.0 (SPSS Inc., Chicago, IL, U.S.A.).

Using the life table, the values of the different reproductive parameters of $S$. eridania were calculated: net reproductive rate $\left(R_{0}\right)$, given by the ratio between the number of females in two successive generations; mean generation time (T), the mean number of days from the birth of the parents to the birth of the offspring; daily intrinsic rate of increase $\left(r_{\mathrm{m}}\right)$; and daily finite rate of increase $(\lambda)$. The means and standard errors of the life-table parameters were estimated based on Jackknife resampling (Maia et al., 2000) and were compared by using a bilateral t-test $(\alpha=0.05)$ (SAS Institute, 2000).

\section{Results}

\subsection{Embryonic period}

The duration of the embryonic period and egg viability of $S$. eridania did not differ when larvae were reared on the artificial diet (4.0 days and 83.39\%) and white clover 
(4.0 days and $84.39 \%$ ) (Table 1 ), but the duration differed $(\mathrm{P}<0.05)$ from the period observed for apple leaves (5.5 days and $49.9 \%$ ).

\subsection{Larval stage}

Neonate larvae of $S$. eridania did not develop when fed on peach leaves cv. 'Chimarrita' and apple fruits cv. 'Gala'. Similarly, when the larvae were maintained on the artificial diet until the $3^{\text {rd }}$ instar and transferred to apple fruits, no individual reached the pre-pupal stage. The duration of the larval stage was shorter when reared on artificial diet (14.1 days) and white clover (16.7 days) in comparison to apple leaves (48.6 days) (Table 1).

\subsection{Pupal stage}

The duration of the pupal stage (Table 1) was influenced by the host and was longer in pupae from larvae fed on apple leaves (15.1 days). There were no significant differences between the artificial diet (9.8 days) and white clover ( 9.9 days), and the viability of the pupal stage on white-clover leaves was higher than that on the artificial diet and apple leaves, i.e., 81.7, 67.0 and $65.7 \%$, respectively.

The mean weight of pupae 24 hours old (Table 2) did not differ between male and female pupae when the larvae were fed on apple leaves, which can be attributed to the small number of experimental units. Pupae (males and females) from larvae fed on the artificial diet gained more weight than the pupae of larvae fed on white-clover and apple leaves, i.e., $0.34,0.22$ and $0.16 \mathrm{~g}$, respectively. The sex ratio was similar among hosts, i.e., close to 0.50 ; females were significantly heavier than males in the treatments with artificial diet and white-clover leaves. The viability of the complete cycle of $S$. eridania for white-clover and apple leaves was higher than the viability on the artificial $\operatorname{diet}(54.3 \%)$, which suggests that this pest is less adapted to artificial diet than to white-clover and apple.

\subsection{Adult stage}

The mean longevity of males and females did not differ significantly among the diets (Table 3 ). However, when the mean values for males and females were compared among

Table 1. Duration (mean \pm SE) and viability (\%) of Spodoptera eridania egg, larva, pupa and total cycle (egg to adult) kept on the artificial diet, white-clover leaves, and apple leaves cv. 'Gala'. Temperature: $25 \pm 1{ }^{\circ} \mathrm{C}, \mathrm{RH} 60 \pm 10 \%$ and photophase: 14 hours.

\begin{tabular}{|c|c|c|c|c|c|}
\hline Food sou & elperiods & Egg & Larva & Pupa & $\begin{array}{c}\text { Cycle } \\
\text { (egg to adult) }\end{array}$ \\
\hline \multirow[t]{2}{*}{ Artificial diet } & Duration (days) & $\begin{array}{l}4.0 \pm 0.0 b^{*} \\
(17)^{1}\end{array}$ & $\begin{array}{c}14.1 \pm 0.2 \mathrm{c} \\
(158)\end{array}$ & $\begin{array}{c}9.8 \pm 0.1 \mathrm{~b} \\
(59)\end{array}$ & $\begin{array}{c}28.5 \pm 0.14 \mathrm{c} \\
(59)\end{array}$ \\
\hline & Viability (\%) & 83.0 & 55.7 & 67.0 & 37.3 \\
\hline \multirow{2}{*}{$\begin{array}{c}\text { White clover } \\
\text { leaves }\end{array}$} & Duration (days) & $\begin{array}{c}4.0 \pm 0.0 \mathrm{~b} \\
(24)\end{array}$ & $\begin{array}{c}16.7 \pm 0.1 \mathrm{~b} \\
\quad(119)\end{array}$ & $\begin{array}{c}9.9 \pm 0.09 \mathrm{~b} \\
\quad(87)\end{array}$ & $\begin{array}{c}30.4 \pm 0.16 b \\
(87)\end{array}$ \\
\hline & Viability (\%) & 84.4 & 91.5 & 81.5 & 54.3 \\
\hline \multirow[t]{2}{*}{ Apple leaves } & Duration (days) & $\begin{array}{c}5.5 \pm 0.7 \mathrm{a} \\
(6)\end{array}$ & $\begin{array}{c}48.6 \pm 1.3 \mathrm{a} \\
(52)\end{array}$ & $\begin{array}{c}15.1 \pm 1.3 \mathrm{a} \\
(34)\end{array}$ & $\begin{array}{c}62.8 \pm 1.2 \mathrm{a} \\
(34)\end{array}$ \\
\hline & Viability (\%) & 49.9 & 67.3 & 65.7 & 23.0 \\
\hline CV $(\%)$ & & 9.56 & 12.11 & 7.49 & 9.94 \\
\hline DF & & 35 & 324 & 178 & 178 \\
\hline $\mathrm{F}$ & & 13.67 & $2,063.85$ & 70.62 & $1,959.39$ \\
\hline
\end{tabular}

*Means followed by the same letters in the row do not differ by Tukey's test at $5 \%$ significance; ${ }^{1}$ Values in parentheses refer to the number of observations.

Table 2. Pupal weight of males and females (Mean \pm SE), sex ratio and number of instars of Spodoptera eridania kept on an artificial diet, white-clover leaves, and apple leaves cv. 'Gala'. Temperature: $25 \pm 1{ }^{\circ} \mathrm{C}, \mathrm{RH} 60 \pm 10 \%$ and photophase: 14 hours.

\begin{tabular}{|c|c|c|c|c|c|}
\hline \multirow{2}{*}{ Host } & \multicolumn{3}{|c|}{ Weight (mg) } & \multirow{2}{*}{ Sex ratio } & \multirow{2}{*}{ Instars } \\
\hline & Males & Females & Males and females & & \\
\hline Artificial diet & $\begin{array}{c}323.8 \pm 4.72 \mathrm{aB}^{*} \\
(43)^{1}\end{array}$ & $\begin{array}{c}364.4 \pm 7.80 \mathrm{aA} \\
(44)\end{array}$ & $\begin{array}{c}345.7 \pm 5.01 \mathrm{a} \\
(87)\end{array}$ & 0.51 & 6 \\
\hline $\begin{array}{l}\text { White-clover } \\
\text { leaves }\end{array}$ & $\begin{array}{c}200.0 \pm 6.37 \mathrm{bB} \\
(58)\end{array}$ & $\begin{array}{c}233.8 \pm 4.34 \mathrm{bA} \\
(61)\end{array}$ & $\begin{array}{c}217.3 \pm 4.11 \mathrm{~b} \\
(119)\end{array}$ & 0.51 & 6 \\
\hline Apple leaves & $\begin{array}{c}156.7 \pm 5.05 \mathrm{cA} \\
(18)\end{array}$ & $\begin{array}{c}155.3 \pm 7.03 \mathrm{cA} \\
(17)\end{array}$ & $\begin{array}{c}156.0 \pm 4.22 \mathrm{c} \\
(35)\end{array}$ & 0.49 & 6 \\
\hline $\mathrm{CV} \%$ & 8.98 & 7.26 & 8.72 & & \\
\hline DF & 118 & 120 & 239 & & \\
\hline $\mathrm{F}$ & 139.09 & 219.88 & 295.59 & & \\
\hline
\end{tabular}

*Means \pm SE followed by the same letters in the line do not differ by Tukey's test at $5 \%$ significance; ${ }^{1}$ Values in parentheses refer to number of observations. 
the diets, $S$. eridania showed a pre-oviposition period of 5.3 and 4.8 days when fed on the artificial diet and apple leaves, respectively, which was significantly longer than the period on white-clover leaves (2.2 days). Mean fecundity was significantly higher in females reared on white-clover leaves compared to those reared on the artificial diet and apple leaves, i.e., 1,560.6, 840.6 and 310.0 eggs per female, respectively (Table 3 ).

The net reproductive rate $\left(R_{0}\right)$ indicated that the population of $S$. eridania, when white clover was the host, can increase $509.4 \pm 35$ times in each generation. On the artificial diet, $R_{0}$ was $336.9 \pm 33$ times, and on apple leaves, only $34.9 \pm 16.3$ times (Table 4 ). The mean generation time (T) was approximately $36.1 \pm 0.3$ days for the artificial diet and $35.1 \pm 0.13$ days for white-clover leaves, which was shorter than for apple leaves (69.9 \pm 1.24 days) in this study. The intrinsic growth rate $\left(r_{\mathrm{m}}\right)$ and finite rate of increase $(\lambda)$ were $0.159 \pm 0.001$ and $1.172 \pm 0.002$ on the artificial diet, different from the values for white-clover $\left(r_{\mathrm{m}}=0.177 \pm 0.002\right.$ and $\left.\lambda=1.194 \pm 0.002\right)$ and apple leaves $\left(r_{\mathrm{m}}=0.053 \pm 0.007\right.$ and $\left.\lambda=0.008 \pm 0.001\right)$.

\section{Discussion}

S. eridania larvae did not feed on peach leaves and apple fruits. Even when fed on these diets until the third instar and transferred to apple fruits, the larvae only damaged the fruit and were unable to molt further. These results demonstrate the occurrence of host resistance to the development of $S$. eridania in these structures, where the observed reduction in development, as with larvae of S. eridania that feed on peach leaves or apple fruits, may be related to poor nutritional quality and the presence of allelochemicals, as observed in annual crops, which mostly affect ecdysis, preventing them from reaching the pupal stage (Reynolds et al., 1984).

Our results showed that the development of $S$. eridania was more strongly affected when used apple as host compared to the other food sources, which showed increases in the duration of the larval and pupal stages and consequently the total cycle duration, as well as a reduction in the weight of pupae. According to Panizzi and Parra (2009), the ingestion of food in the early stages of development is an important factor for polyphagous insects, because some nutrients present in the hosts can supply the nutritional needs of the insect, supporting normal development until the adult stage. Thus, inadequate food sources delay development, as observed on bracatinga M. scabrella (Mattana and Foerster, 1988), strawberry and grape (Bortoli et al., 2012), and an artificial diet (López and López, 2010). However, when the insect feeds on a suitable food source, the insect/host response is better, with a shorter development period and greater viability, as observed for other food sources, such as cotton Gossypium hirsutum, morning-glory Ipomoea grandifolia and soybean Glycine max (Santos et al., 2005). Thus,

Table 3. Longevity of males and females, pre-oviposition (days) (mean \pm SE) and eggs per female (mean \pm SE) of Spodoptera eridania kept on the artificial diet, white clover leaves, and apple leaves cv. 'Gala'. Temperature: $25 \pm 1^{\circ} \mathrm{C}, \mathrm{RH}$ $60 \pm 10 \%$ and photophase: 14 hours.

\begin{tabular}{|c|c|c|c|c|}
\hline \multirow{2}{*}{ Host } & \multicolumn{2}{|c|}{ Longevity (days) } & \multirow{2}{*}{ Pre-oviposition (days) } & \multirow{2}{*}{ Fertility } \\
\hline & Males & Females & & \\
\hline Artificial diet & $\begin{array}{c}17.2 \pm 0.98 \mathrm{a}^{*} \\
(17)^{1}\end{array}$ & $\begin{array}{c}14.8 \pm 1.14 \mathrm{a} \\
(17)\end{array}$ & $\begin{array}{c}5.3 \pm 1.08 \mathrm{a} \\
(8)\end{array}$ & $\begin{array}{c}840.6 \pm 236.7 b \\
(17)\end{array}$ \\
\hline White clover leaves & $\begin{array}{c}16.5 \pm 0.87 \mathrm{a} \\
(24)\end{array}$ & $\begin{array}{c}15.44 \pm 0.86 a \\
(24)\end{array}$ & $\begin{array}{c}2.2 \pm 0.09 \mathrm{~b} \\
(25)\end{array}$ & $\begin{array}{c}1560.6 \pm 107.8 \mathrm{a} \\
(27)\end{array}$ \\
\hline Apple leaves & $\begin{array}{c}7.33 \pm 1.30 b \\
(6)\end{array}$ & $\begin{array}{c}9.83 \pm 1.51 \mathrm{a} \\
(6)\end{array}$ & $\begin{array}{c}4.83 \pm 1.01 \mathrm{a} \\
(6)\end{array}$ & $\begin{array}{c}310.0 \pm 145.3 \mathrm{~b} \\
\text { (6) }\end{array}$ \\
\hline $\mathrm{CV}(\%)$ & 24.41 & 15.71 & 16.53 & 48.84 \\
\hline DF & 46 & 46 & 38 & 49 \\
\hline $\mathrm{F}$ & 15.96 & 2.97 & 16.79 & 11.37 \\
\hline
\end{tabular}

*Means \pm SE followed by the same letters in the line do not differ by Tukey's test at $5 \%$ significance; ${ }^{1}$ Values in parentheses refer to the number of observations.

Table 4. Mean generation time $(\mathrm{T})$, net reproductive rate $\left(R_{0}\right)$, intrinsic rate of population increase $\left(r_{\mathrm{m}}\right)$ and daily finite rate of increase $(\lambda)$ for Spodoptera eridania kept on the artificial diet, white-clover leaves, and apple leaves cv. 'Gala'. Temperature: $25 \pm 1{ }^{\circ} \mathrm{C}$, RH $60 \pm 10 \%$ and photophase: 14 hours.

\begin{tabular}{ccccc}
\hline Diets & T (days) & $R_{\mathbf{0}}(q / q)$ & $\boldsymbol{r}_{\mathbf{m}}\left(q /{ }^{*}\right.$ day) & $\begin{array}{c}\boldsymbol{\lambda} \\
\text { (individuals } /+/ \text { day) }\end{array}$ \\
\hline Artificial diet & $36.11 \pm 0.30 \mathrm{~b} *$ & $336.92 \pm 33.2 \mathrm{~b}$ & $0.16 \pm 0.001 \mathrm{~b}$ & $1.17 \pm 0.002 \mathrm{~b}$ \\
White-clover leaves & $35.13 \pm 0.13 \mathrm{a}$ & $509.39 \pm 34.9 \mathrm{a}$ & $0.18 \pm 0.002 \mathrm{a}$ & $1.19 \pm 0.002 \mathrm{a}$ \\
Apple leaves & $69.9 \pm 1.24 \mathrm{c}$ & $34.9 \pm 16.3 \mathrm{c}$ & $0.05 \pm 0.007 \mathrm{c}$ & $0.01 \pm 0.001 \mathrm{c}$ \\
$P$ value & $<0.0001$ & $<0.0001$ & $<0.0001$ & $<0.0001$ \\
\hline
\end{tabular}

*Values represent mean \pm SEM obtained with the Jackknife method through the SAS program. For each parameter evaluated, values followed by the same letter in the column do not differ statistically from each other $(\mathrm{P}>0.05)$. 
although apple leaves can support the development of the larval stage, it is not a suitable host for complete development of $S$. eridania, such as the diet developed by Greene et al. (1976), Montezano et al. (2014), which showed that the larvae had a poor development.

The duration of the pupal stage was influenced by the host, in agreement with the results for S. eridania fed on strawberry and grape leaves (Bortoli et al., 2012). However, S. eridania had a shorter pupal stage when fed on velvet bean Stizolobium aterrimum, pigeon pea Cajanus cajan, jack bean Canavalia ensiformes, oilseed radish Raphanus sativus and sunn hemp Crotalariajuncea at ambient temperatures (Jesus et al., 2013). The mean pupal weight of males and females did not differ when the larvae were fed on apple leaves, which can be attributed to the low number of pupae evaluated. Pupae (males and females) from larvae fed on the artificial diet gained more weight than the pupae of larvae fed on white-clover and apple leaves. The lower weight of pupae from larvae fed on apple leaves may be related to a non-preference of larvae for the food or ingestion of substances in the leaves (allelochemicals), causing antibiosis and impeding their development, or even to both factors combined, which fosters host resistance to the attack of defoliators (Santos and Boiça-Júnior, 2001).

Several studies have shown that the development of S. eridania is influenced by the host, especially when it uses food sources from perennial crops, where it shows lower viability and increased duration of the entire cycle, as seen on apple and peach leaves in this study and by Bortoli et al. (2012) for grapes, compared to short-cycle (annual) crops such as cotton, where the viability is higher and the total cycle is shorter (Santos et al., 2005). However, larvae may be less viable on these annual crops, as observed for soybean by Santos et al. (2005). Thus, the effects on the biological parameters observed for peach leaves and fruits and leaves of apple may reflect the expression of some protective mechanism (resistance), in which the insect feeds on the plant and its development is affected. This resistance mechanism would have an adverse effect at some stage of development, which may cause high mortality in the immature stages, reduction in size or weight, change the sex ratio, and shorter life span (Smith, 2005).

For the hosts evaluated here, the mean longevity of males did not differ from that of females. Bortoli et al. (2012) found no significant differences in the longevity of male and female $S$. eridania on strawberry and grape leaves. However, in the present study, adults originated from larvae reared on apple leaves had shorter life spans. Santos et al. (2005) also observed reduced longevity of adults from larvae fed on cotton, soybeans and morning-glory, compared to those observed in the present study for adults from larvae fed on the artificial diet and white clover. These results indicate that the artificial diet and white clover provide adequate nutrition, while improving the larval development and adults longevity. The greater longevity of adults may also be related to non-fertilization of females, or if they are fertilized later by males (Montezano et al., 2013, 2014).
The pre-oviposition period observed in the present study was longer on the artificial diet and the white-clover and apple leaves. These results may be associated with the host or with the reduced number of copulations at this development stage, as reported by Montezano et al. (2013), which is reflected in the increase in longevity. The shortest pre-oviposition period was observed by Mattana and Foerster (1988) for bracatinga Mimosa scrabella and sweet potato Ipomoea batatas. López and López (2010) also found a long pre-oviposition period in S. eridania fed on the artificial diet, with longer periods than when it was fed on soybean leaves.

Females that were fed on white-clover in the larval phase showed higher fertility than females from individuals fed on apple leaves and the artificial diet. Santos et al. (2005) found fertility values similar to those observed in apple leaves and the artificial diet when females were fed on cotton. López and López (2010) found similar values to other results when females were reared on the artificial diet in the larval stage. The mean fertility observed for females reared on white-clover was similar to that observed on soybean (Parra et al., 1977), sweet-potato (Mattana and Foerster, 1988), strawberry and grape (Bortoli et al., 2012). These results show that white-clover has a higher nutritional value than apple for the development of $S$. eridania. In this case, differences in the amount of food ingested or physical or chemical differences among the foods may have been responsible for these effects on reproduction (Johansson, 1964).

The net reproductive rate $\left(R_{0}\right)$ of $S$. eridania varied widely, and the response also varies between cultivated plants and spontaneous plants (Santos et al., 2005). The $R_{0}$ also differed between strawberry and grape in trials by Bortoli et al. (2012). The $R_{0}$ indicated that the population of $S$. eridania, when white-clover was the host, can increase 225.71 times in each generation. The $R_{0}$ was 118.18 times for the artificial diet, and only 48 times for apple leaves (Table 4). The mean generation times (T) observed with the artificial diet and white clover were shorter than those observed by Bortoli et al. (2012) in larvae fed on strawberry $(\mathrm{T}=59.1)$ and grape $(\mathrm{T}=48.8$ at $22^{\circ} \mathrm{C}$ ), but similar to values obtained by Montezano et al. (2013) for the artificial diet (35.8 days at $25^{\circ} \mathrm{C}$ ).

The intrinsic rates of increase $\left(r_{\mathrm{m}}\right)$ and finite rates of increase $(\lambda)$ on white-clover and the artificial diet were similar to those observed by Montezano et al. (2013), and higher than those observed on apple leaves. These values were also similar to those reported by Bortoli et al. (2012) in strawberry and grape. However, one must consider that the values for the same species vary widely, especially as a function of temperature, host plant, or rearing on an artificial diet (Parra et al., 1977; Mattana and Foerster, 1988; Bavaresco et al., 2002; Santos et al., 2005).

The present results showed that white-clover, when present as a cover crop in apple and peach orchards, is a suitable host for the development of S. eridania. In the case of commercial orchards, $S$. eridania cannot grow on peach leaves, while the viability of the pest on apple 
leaves is low and unsuitable for the development of the species, although it can complete its life cycle. In this case, $S$. eridania can develop on suitable species such as white-clover present in apple and peach orchards. The damage caused by S. eridania is possibly due to "test bites" made in fruits, usually at night, even though the fruit is not a suitable host species for the larvae. Thus, inadequate management practices, such as herbicide application, elimination of cover crops, and reduction of the food source used by larvae, result in infestation and damage to fruit trees after these commercial crops have become established.

\section{Acknowledgements}

The authors acknowledge the Coordination for the Improvement of Higher Education Personnel (Coordenação de Aperfeiçoamento de Pessoal de Nível Superior - CAPES) for financial support and granting scholarships to the authors.

\section{References}

BAVARESCO, A., GARCIA, M.S., GRÜTZMACHER, A.D., RINGENBERG, R. and FORESTI, J., 2002. Biologia e exigências térmicas de Spodoptera cosmioides (Walk.) (Lepidoptera: Noctuidae). Neotropical Entomology, vol. 31, no. 1, pp. 49-54. http://dx.doi.org/10.1590/S1519-566X2002000100007.

BORTOLI, L.C., BERTIN, A., EFROM, C.F.S. and BOTTON, M., 2012. Biologia e tabela de vida de fertilidade de Spodoptera eridania (Cramer) (Lepidoptera: Noctuidae) em morangueiro e videira. Revista Brasileira de Fruticultura, vol. 34, no. 4, pp. 1068-1073. http://dx.doi.org/10.1590/S0100-29452012000400013.

BORTOLOTTO, O.C., SILVA, G.V., FREITAS BUENO, A., POMARI, A.F., MARTINELLI, S., HEAD, G.P., CARVALHO, R.A. and BARBOSA, G.C., 2014. Development and reproduction of Spodoptera eridania (Lepidoptera: Noctuidae) and its egg parasitoid Telenomus remus (Hymenoptera: Platygastridae) on the genetically modified soybean (Bt) MON 87701 x MON 89788. Bulletin of Entomological Research, vol. 104, no. 6, pp. 724-730. http://dx.doi.org/10.1017/S0007485314000546. PMid:25248849.

BOTTON, M., ARIOLI, C.J., SILVA, A. and BARONIO, C.A., 2012. [viewed 25 November 2016]. Efeito adverso. Cultivar Hortaliças Frutas [online], vol. 11, no. 74, pp. 14-15. Available from: http://www.grupocultivar.com.br/acervo/166.

BURTON, R.L. and PERKINS, W.D., 1972. WSB, a new laboratory diet for the corn earworm and the fall armyworm. Journal of Economic Entomology, vol. 65, no. 2, pp. 385-386. http://dx.doi.org/10.1093/jee/65.2.385.

BUTT, B.A. and CANTU, E., 1962. Sex determination of lepidopterous pupae. Washington: Department of Agriculture, 7 p. Agriculture Research Service, no. ARS-33-75.

CAPINERA, J.L., 1999 [viewed 18 August 2014]. Southern armyworm, Spodoptera eridania (Cramer) (Insecta: Lepidoptera: Noctuidae) [online]. Florida: University of Florida, 7 p. Available from: http://edis.ifas.ufl.edu/in263.

EFROM, C.F.S., BORTOLI, L.C., BERTIN, A., SPECHT, A. and BOTTON, M., 2014 [viewed 03 December 2016]. Bioecologia e Controle de Spodoptera eridania (Lepidoptera: Noctuidae) em Videira no Rio Grande do Sul [online]. Bento Gonçalves: Embrapa
Uva e Vinho, 7 p. Embrapa Uva e Vinho. Comunicado Técnico, 150. Available from: http://www.infoteca.cnptia.embrapa.br/ handle/doc/991754.htm

FAVETTI, B.M., BUTNARIU, A.R. and FOERSTER, L.A., 2015. Biology and reproductive capacity of Spodoptera eridania (Cramer) (Lepidoptera, Noctuidae) in different soybean cultivars. Revista Brasileira de Entomologia, vol. 59, no. 2, pp. 89-95. http://dx.doi.org/10.1016/j.rbe.2015.03.002.

FONSECA, F.L., 2006. Ocorrência, monitoramento, caracterização de danos e parasitismo de Noctuidae e Geometridae em pomares comerciais de macieira em Vacaria, RS, Brasil. Curitiba: Universidade Federal do Paraná, 97 p. Tese de doutorado em Ciências.

GREENE, G.L., LEPPLA, N.C. and DICKERSON, W.A., 1976. Velvet bean caterpillar: a rearing procedure and artificial medium. Journal of Economic Entomology, vol. 69, no. 4, pp. 488-497. http://dx.doi.org/10.1093/jee/69.4.487.

JESUS, F.G., SOUSA, P.V., MACHADO, B.R., PEREIRA, A.I.A. and ALVES, G.C.S., 2013. Desenvolvimento de Spodoptera eridania (Cramer) (Lepidoptera: Noctuidae) em diferentes hospedeiros. Arquivos do Instituto Biológico, vol. 80, no. 4, pp. 430-435. http://dx.doi.org/10.1590/S1808-16572013000400009.

JOHANSSON, A.S. 1964. Feeding and nutrition in reproductive processes in insects. In: Proceedings of the 2nd Symposium Of The Royal Entomological Society, 1964, London, UK. London: Royal Entomological Society, pp. 43-55.

LÓPEZ, M.B.R. and LÓPEZ, V.A.G., 2010. Biología de Spodoptera eridania (Cramer, 1782) (Lepidoptera: Noctuidae) em dieta natural y artificial, em condiciones de laboratório. Investigación Agraria, vol. 12 , no. 1 , pp. 17-21.

MAIA, A.H., LUIZ, A.J. and CAMPANHOLA, C., 2000. Statistical inference on associated fertility life table parameters using Jackknife technique: computational aspects. Journal of Economic Entomology, vol. 93, no. 2, pp. 511-518. http://dx.doi. org/10.1603/0022-0493-93.2.511. PMid:10826207.

MATTANA, A.L. and FOERSTER, L.A., 1988. Consumo e utilização de bracatinga (Mimosa scrabella, Bentham) (Leguminosae) e batata doce (Ipomoea batatas L.) (Convolvulaceae) por larvas de Spodoptera eridania (Cramer, 1782) (Lepidoptera: Noctuidae). Anais da Sociedade Entomológica do Brasil, vol. 17, pp. 95-105.

MIRANDA, M.M.M., PICANÇO, M.C., ZANUNCIO, J.C., BACCI, L. and SILVA, E.M., 2005. Impact of integrated pest management on the population of leafminers, fruit borers, and natural enemies in tomato. Ciência Rural, vol. 35, no. 1, pp. 204-208. http://dx.doi.org/10.1590/S0103-84782005000100033.

MONTEZANO, D.G., SPECHT, A., SOSA-GÓMEZ, D.R., ROQUE-SPECHT, V.F. and BARROS, N.M., 2013. Biotic potential and reproductive parameters of Spodoptera eridania (Stoll) (Lepidoptera, Noctuidae) in the laboratory. Revista Brasileira de Entomologia, vol. 57, no. 3, pp. 340-346. http:// dx.doi.org/10.1590/S0085-56262013005000026.

MONTEZANO, D.G., SPECHT, A., SOSA-GÓMEZ, D.R., ROQUE-SPECHT, V.F. and DE BARROS, N.M., 2014. Immature stages of Spodoptera eridania (Lepidoptera: Noctuidae): developmental parameters and host plants. Journal of Insect Science, vol. 14, no. 1, pp. 1-11. http://dx.doi.org/10.1093/jisesa/ ieu100. PMid:2552 5103.

NORA, I. and REIS FILHO, W., 1988. Damage to apple (Malus domestica, Bork.) caused by Spodoptera spp. (Lepidoptera: 
Noctuidae). Acta Horticulturae, no. 232, pp. 209-212. http:// dx.doi.org/10.17660/ActaHortic.1988.232.28.

NUNES, J.C., SANTOS, R.S.S. and BOFF, M.I.C., 2013. Identificação e comportamento ecológico de mariposas em pomar de macieira. Revista de la Facultad de Agronomía, vol. 112 , no. 1, pp. 51-61.

PANIZZI, A.R. and PARRA, J.R.P. 2009. Introdução à bioecologia e nutrição de insetos como base para o manejo integrado de pragas. In: A.R. PANIZZI, J.R.P. PARRA, eds. Bioecologia e nutrição de insetos: base para o manejo integrado de pragas. Brasília: Editora Embrapa, pp. 21-36.

PARRA, J.R.P., PRECETTI, A.A.C.M. and KARSTEN-JR, P., 1977. Aspectos biológicos de Spodoptera eridania (Cramer, 1782) (Lepidoptera: Noctuidae) em soja e algodão. Anais da Sociedade Entomológica do Brasil, vol. 6, pp. 147-155.

POGUE, M.G., 2002. A world revision of the genus Spodoptera Guenée (Lepidoptera: Noctuidae). Memoirs of the American Entomolological Society, vol. 43, no. 28, pp. 117-124.

REYNOLDS, G.W., SMITH, C.M. and KESTER, K.M., 1984. Reductions in consumption, utilization, and growth rate of soybean looper (Lepidoptera: Noctuidae) larvae fed foliage of soybean genotype PI 227687. Journal of Economic Entomology, vol. 77, no. 6, pp. 1371-1375. http://dx.doi.org/10.1093/jee/77.6.1371.
SANTOS, K.B., MENEGUIM, A.M. and NEVES, P.M.O.J., 2005. Biologia de Spodoptera eridania (Cramer) (Lepidoptera: Noctuidae) em diferentes hospedeiros. Neotropical Entomology, vol. 34, no. 6, pp. 903-910. http://dx.doi.org/10.1590/S1519$566 \times 2005000600005$.

SANTOS, K.B., MENEGUIM, A.M., SANTOS, W.J., NEVES, P.M. and SANTOS, R.B., 2010. Caracterização dos danos de Spodoptera eridania (Cramer) e Spodoptera cosmioides (Walker) (Lepidoptera: Noctuidae) a estruturas de algodoeiro. Neotropical Entomology, vol.39, no. 4, pp. 626-631. http://dx.doi.org/10.1590/ S1519-566X2010000400025. PMid:20878002.

SANTOS, T.M. and BOIÇA JÚNIOR, A.L., 2001. Resistência de genótipos de algodoeiro (Gossypium hirsutum L.) a Alabama argillacea (Hübner) (Lepidoptera: Noctuidae). Neotropical Entomology, vol. 30, no. 2, pp. 297-303. http://dx.doi.org/10.1590/ S1519-566X2001000200014.

SAS INSTITUTE (2000). Statistical analysis system: getting started with the SAS learning. Cary: SAS Institute.

SHAPIRO, S.S. and WILK, M.B., 1965. An analysis of variance test for normality (complete samples). Biometrika, vol. 52, no. 4, pp. 591-611. http://dx.doi.org/10.1093/biomet/52.3-4.591.

SMITH, C.M. 2005. Plant resistance to arthropods: molecular and conventional approaches. Dordrecht: Springer, 423 p. http:// dx.doi.org/10.1007/1-4020-3702-3. 